Jakub Puziuk

Muzeum Archeologiczne w Krakowie

ORCID ID: 0000-0002-3055-9898
OBLICZA WOJNY

TOM $3 \cdot$ MIASTO I WOJNA

ŁÓDŹ $2021 \cdot$ ISBN 978-83-8220-556-5 • s. 99-116

https://doi.org/10.18778/8220-556-5.06

\title{
MIEJSKA TRADYCJA FAJCZARSKA W ETOSIE ŻOŁNIERSKIM. ZNALEZISKA ARCHEOLOGICZNE AKCESORIÓW DO PALENIA TYTONIU W KONTEKŚCIE ŻOŁNIERZY STACJONUJACYCH NA WAWELU W KRAKOWIE
}

\begin{abstract}
Streszczenie. W okresie nowożytnym palenie tytoniu spełniało u żołnierzy nie tylko funkcję relaksacyjną, ale również stanowiło specyficzną terapię leczniczą. Roślina ta przez długi czas postrzegana była przez pryzmat terapeutycznego zioła (herba panacea), polecanego jako uniwersalny preparat medyczny. Kultura palenia tytoniu w fajce osiągnęła wysoki stopień rozwoju zwłaszcza w krajach Monarchii Habsburgów i późniejszym państwie austro-węgierskim, co potwierdzać mogą znaleziska archeologiczne przyborów związanych z tym okresem. Interpretacja kontekstu historycznego takich źródeł bardzo często wskazuje, że ich użytkownikami było środowisko żołnierskie, które zwłaszcza w czasach dominacji Austro-Węgier licznie stacjonowało w rozbudowanej sieci fortów i koszar, często znajdujących się na obszarach miast. Przykładem takiego ośrodka miejskiego, stanowiącego jedną z kluczowych baz wojskowych, był Kraków. Najważniejszym punktem obrony budowanej w Krakowie twierdzy było wzgórze wawelskie, które w 1848 r. oficjalnie przekazano na koszary dla wojsk austriackich. Badania archeologiczne realizowane na Wawelu w latach 1948-2011 doprowadziły do odkrycia najliczniejszego obecnie zbioru nowożytnych fajek na terenie Małopolski. Najokazalsze są znaleziska fajek złożonych - lulek oraz przyborów porcelanowych, które stanowią materialny ślad obecności wojsk austriackich i austro-węgierskich w XIX w. i początkach wieku XX. Prace te dowodzą, że wśród żołnierzy stacjonujących na Wawelu znaczną popularnością cieszyły się sygnowane lulki o wysokiej jakości rzemiosła, produkowane w różnych zakładach działających na terenie krajów Imperium Habsburskiego i późniejszych Austro-Węgier. Żołnierze oddawali się nałogowi palenia tytoniu również w innym rodzaju lulki, która znana jest pod nazwą fajki „kawiarnianej". Pojawienie się tego typu akcesoriów związane było z dziewiętnastowieczną modą, popularną szczególnie wśród mieszczan Europy środkowej, która upowszechniała tzw. kulturę kawiarnianą, polegającą na spędzaniu wolnego czasu przy piciu kawy i paleniu fajki w miejskich kawiarniach. W asortymencie dziewiętnastowiecznych akcesoriów do palenia tytoniu wykorzystywanych przez żołnierzy, zaznaczają się także fajki porcelanowe. Charakterystycznymi
\end{abstract}


ich pozostałościami są porcelanowe główki oraz wykonywane z tego samego materiału zbiorniki kondensatowe. Istnieje duże prawdopodobieństwo, że tego typu przybory rozpoznane na Wawelu stanowią fragmenty tzw. fajek rezerwistów, które jako pamiątki otrzymywali żołnierze odchodzący ze służby w krakowskiej cytadeli. Pozostałości fajek zidentyfikowane w kontekście żołnierzy stacjonujących na krakowskim Wawelu odzwierciedlają przywiązanie tego środowiska do nałogu tytoniowego, który praktykowany był w akcesoriach nawiązujących do wschodnioeuropejskiego modelu palenia. Tytoń ceniony był nie tylko za swoje wartości relaksacyjne, ale spełniał również niepoślednią rolę w procesie zdrowienia i psychicznej rehabilitacji żołnierzy, czego dowodzą znaczne ilości znalezisk fajek w rejonach zabudowań dawnego szpitala garnizonowego. Zaznacza się ponadto wpływ miejskiej kultury palenia, która inspirowała żołnierzy do przyjęcia niektórych obyczajów i praktyk spędzania wolnego czasu z fajką, czego najlepszym przykładem są odkrycia na wawelskim wzgórzu akcesoriów „kawiarnianych”.

Słowa kluczowe: fajka złożona - lulka, fajka porcelanowa, Kraków, Wawel, Austro-Węgry, Imperium Habsburskie, Twierdza Kraków, palenie tytoniu

Tradycja związana z paleniem tytoniu w fajce, już w początkach pojawienia się jej w kulturze nowożytnej Europy, była domeną głównie środowiska marynarskiego. Wielu badaczy eksponowało w tym aspekcie wpływ działalności angielskich żeglarzy i korsarzy, w szczególności sir Waltera Raleigha (1554-1618), który spopularyzował nieznaną dotąd modę na dworze królowej angielskiej Elżbiety I (1558-1603) ${ }^{1}$. To żeglarze przywozili do Europy pierwsze egzemplarze fajek indiańskich, które stały się pierwowzorem najstarszych w zachodniej części Starego Kontynentu akcesoriów nazywanych fajkami jednorodnymi. Przełomem, który rozpoczął „karierę” tych przyborów wśród mieszańców nie tylko Europy zachodniej, był wielonarodowy konflikt zbrojny zwany wojną trzydziestoletnią (1618-1648), w której żołnierze różnych armii stali się swoistymi „ambasadorami” fajki i propagatorami nowego nałogu².

Palenie tytoniu dla żołnierzy w okresie nowożytnym miało nie tylko wartość relaksacyjną, ale przede wszystkim stanowić miało specyficznego rodzaju terapię leczniczą. Warto zauważyć, że roślina ta przez długi czas postrzegana była przez

${ }^{1}$ K. MeYZA, Fajki gliniane $z$ XVII w. ipierwszejpotowy XVIII w. z badań archeologicznych Zamku Królewskiego i Starego Miasta w Warszawie, „Almanach Muzealny” 1997, t. 1, s. 31-44; J. PuZIUK, Fajki z badań archeologicznych $w$ Krakowie - źródto mówiące o tradycji, obyczajach i handlu mieszkańców nowożytnego miasta, [w:] Zielonogórskie Spotkania Źródtoznawcze. Na tropie źródta i jego interpretacji, red. M. DAlidowicz, J. DudeK, A. GÓRSKi, Zielona Góra 2015, s. 78; M. SZeWCZYK-WojTASIEWICZ, Fajki z badań archeologicznych w zbiorach Zamku Królewskiego na Wawelu, Kraków 2017, s. 16.

2 T. Witkowska, Fajki z badań archeologicznych na placu Dominikańskim we Wroctawiu, „Silesia Antiqua" 1998, t. 39, s. 289. 
pryzmat terapeutycznego zioła (herba panacea), polecanego jako uniwersalny preparat medyczny m.in. na bóle głowy, żołądka, gnicie dziąseł czy wrzody ${ }^{3}$. Od połowy XVII w. używka ta była rekomendowana również w polskim wojsku, gdzie wraz z alkoholem (gorzałką) stanowić miała znakomity środek dezynfekujący, pomagający jednocześnie przetrwać trudne warunki zmiennej aury $^{4}$. O ważnej roli, jaką spełniała fajka w egzystencji nowożytnego żołnierza, przekonany był generał armii Napoleona Bonapartego Antoine Fortune de Brack (1789-1850), który spisując wspomnienia i doświadczenia wojenne, tak podkreślał znaczenie nałogu tytoniowego:

Każdego żołnierza należy zachęcać do palenia fajki (...) ponieważ paląc ją, nie zasypia. Ukaja, pozwala ukrócić nudę, zwalcza nieprzyjemne myśli i zatrzymuje żołnierza w obozie przy koniu. Póki żołnierz siedzi na stercie siana lub trawy i pali fajkę, nikt nie próbuje podkraść furaż jego konia, by dać swojemu. Jakąż pociechę można (...) znaleźć w fajce, która spędzi senność, przyśpieszy upływający czas, uczyni deszcz mniej zimnym, a głód i pragnienie łatwiejszym do zniesienia! Z tych względów (...) palcie i niech podobnie czynią Wasi podkomendnis.

Kultura palenia tytoniu w fajce, osiągnęła wysoki stopień rozwoju zwłaszcza w krajach Monarchii Habsburgów i późniejszym państwie austro-węgierskim, co potwierdzać również mogą znaleziska archeologiczne akcesoriów związanych z tym okresem m.in. z Czech, Serbii oraz ze Słowacji ${ }^{6}$. Interpretacja kontekstu historycznego takich źródeł bardzo często wskazuje, że ich użytkownikami było środowisko żołnierskie, które przede wszystkim w czasach dominacji Austro-Węgier licznie stacjonowało w rozbudowanej sieci fortów i koszar, często znajdujących się na terenach miast (ryc. 1-2) ${ }^{7}$.

${ }^{3}$ J. KUŚNIERZ, Ceramiczne gtówki fajek ze zbiorów Muzeum Zamojskiego w Zamościu na tle krótkiej historii palenia tytoniu w Europie i Polsce, „Zamojsko-Wołyńskie Zeszyty Muzealne” 2014, t. 6, s. 123. Warto w tym miejscu dodać, że szkodliwość tytoniu dla ludzkiego zdrowia, udało się potwierdzić dopiero w 1828 r. - vide: K. KWIATKOWSKI, Ulotna historia. Fajki gliniane z badań w Stargardzie, Stargard 2012, s. 2.

${ }^{4}$ J. KUŚNIERZ, op. cit., s. 132.

5 A.F. De BraCK, Forpoczty kawalerii lekkiej. Wspomnienia, Oświęcim 2012, s. 76.

${ }^{6}$ M. VYŠOHLíD, Bohemia, „Journal of the Académie Internationale de la Pipe” 2009, vol. 2, s. 20; D. GAČIĆ, The pipes from museum collections of Serbia, Novi Sad 2011, s. 31-35; M. BIELICH, Nálezy fajok zo Šale a okolia, „Študijné zvesti Archeologického ústavu Slovenskej Akademie Vied” 2016, Roč. 59, s. 131-138.

7 Dobrym przykładem są znaleziska z twierdzy znajdującej się w serbskim mieście Petrovaradin, gdzie rozpoznane fajki stanowiły pozostałość obecności wojsk tureckich i austro-węgierskich - vide: 

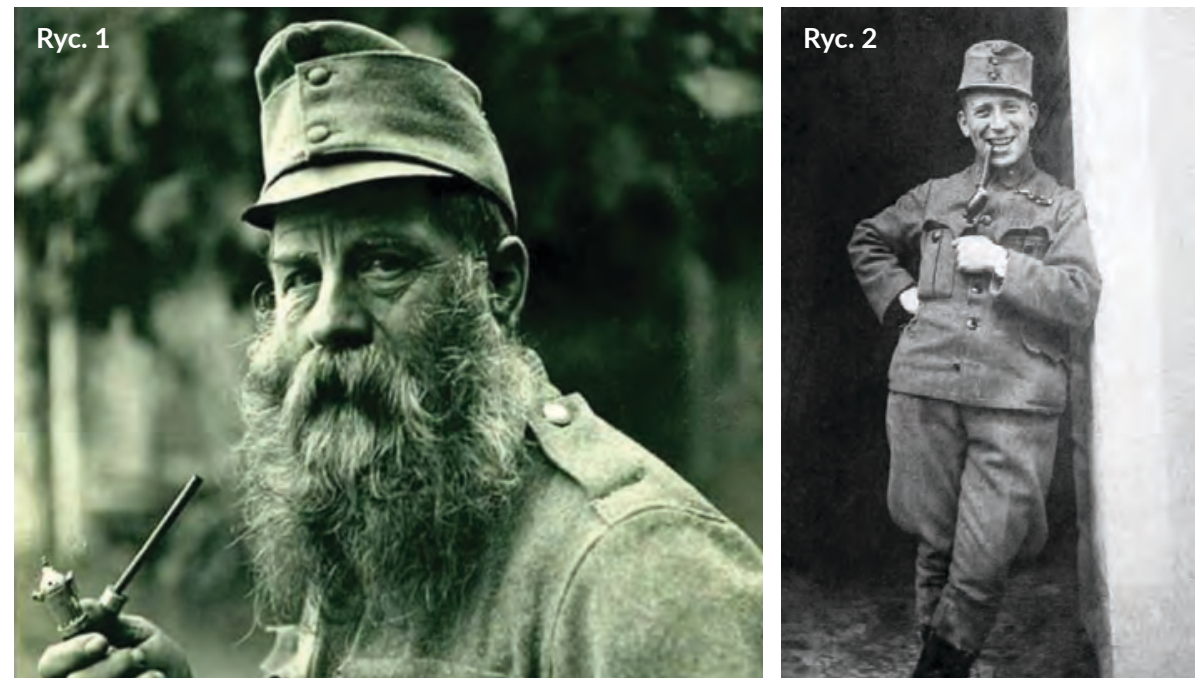

Ryc. 1. Żołnierz austro-węgierski palący fajkę złożoną - lulkę (źródło: https://pl.pinterest.com/pin/729090627173767948/, dostęp: 16 XII 2020)

Ryc. 2. Żołnierz austro-węgierski palący fajkę (źródło: https://pl.pinterest.com/pin/729090627173768025/, dostęp: 16 XII 2020)

Przykładem takiego ośrodka miejskiego, stanowiącego jedną z kluczowych baz wojskowych, był Kraków, który w XIX w. wskutek działania władz austriackich przekształcono w miejsce znacznej koncentracji żołnierzy. Miasto to w strategii wojennej władz Monarchii Habsburskiej pełnić miało rolę ważnego punktu obronnego, co już po decyzji cesarskiej w 1850 r. zaczęto sukcesywnie realizować, tworząc szereg założeń fortyfikacyjnych projektu nowej twierdzy ${ }^{8}$. Do 1854 r. Austriacy wznieśli w Krakowie wiele fortów, budując takie dzieła obronne wokół kopców Kościuszki i Kraka, na Krzemionkach, Prądniku oraz przy kościele św. Benedykta9. Prace te zostały zintensyfikowane zwłaszcza w czasie wojny krymskiej (1853-1856), kiedy umocniono szereg punktów wokół

D. GAČIĆ, Glinene lule sa Petrovaradinske tvrdave, „Journal Museum of Applied Art” 2008/2009, Jou. 4/5, s. 15-16; Pipes from Petrovaradin fortress, Serbia, in the collection of Novi Sad City Museum, "Journal of the Académie Internationale de la Pipe" 2010, vol. 3, s. 125.

8 J. Bieniarzówna, J.M. MaŁecki, Dzieje Krakowa. Kraków w latach 1796-1918, t. 3, Kraków 1979, s. 203.

9 Vide: Zabytki architektury i budownictwa w Polsce - Kraków, red. J. CzaJ-Waluś, Warszawa 2007 , s. 58-62. 
miasta, wznosząc nawet fortyfikacje w niewielkiej odległości od miejskiego Rynku (około $1 \mathrm{~km}$ ), m.in. u wylotów ulic Długiej i Lubicz czy na Grzegórz$\mathrm{kach}^{10}$. Najistotniejszym punktem obrony budowanej w Krakowie twierdzy, było wzgórze wawelskie, które w 1848 r. oficjalnie przekazano na koszary dla wojsk austriackich ${ }^{11}$. W latach 1848-1860 przekształcono je w cytadelę górującą nad miastem, najpierw otaczając szańcami i palisadami, później natomiast budując mury obronne ze strzelnicami ${ }^{12}$. Koncepcję otoczenia Wawelu pierścieniem fortyfikacji, autorstwa Corneliusa Rittera von Würma, zrealizowano w latach 1850-1853, wznosząc w tym czasie dwie kaponiery oraz cztery bramy wjazdowe ${ }^{13}$. Prace remontowe prowadzono również na dawnym zamku królewskim, gdzie w latach 1854-1856, pod kierunkiem Feliksa Księżarskiego, dokonano licznych przekształceń wyglądu pomieszczeń i konstrukcji budynku, mających na celu adaptację do celów koszarowych ${ }^{14}$. Austriacy dokonali ponadto na wzgórzu wawelskim licznych wyburzeń, które w części południowo-zachodniej skutkowały wzniesieniem okazałego dwuskrzydłowego gmachu szpitala wojskowego ${ }^{15}$. Cytadela na Wawelu stała się zatem swoistego rodzaju „miastem” wojskowym, zapewniającym żołnierzom poczucie ochrony, miejsce zamieszkania oraz opiekę medyczną.

Kraków znajdował się w okresie nowożytnym pod znacznym wpływem obyczajowości tureckiej, płynącej głównie z terenów objętych panowaniem osmańskim. Nie bez znaczenia były w tym kontekście również kontakty handlowe, dzięki którym do mieszkańców Krakowa docierać mogły zarówno tradycje, jak i zagraniczne towary, a wśród nich niemałą rolę odgrywały również fajki o tureckich wzorcach. Tezę tą potwierdzać mogą badania archeologiczne, które rejestrują znaczne ilości znalezisk pozostałości fajek złożonych w odmianie lulki, co dowodzi, że krakowscy mieszczanie oddawali się wschodnioeuropejskiemu modelowi palenia tytoniu ${ }^{16}$. Trudno powiedzieć, czy przybywający do tego miasta

10 J. Bieniarzówna, J.M. MaŁECKI, op. cit., s. 204.

11 R. SKowron, Wawel. Kronika dziejów, Kraków 2001, s. 271.

12 J. Bieniarzówna, J.M. MaŁeCKi, op. cit., s. 203.

${ }_{13}$ R. SKOWRON, op. cit., s. 272.

${ }^{14}$ Ibidem.

15 Ibidem.

16 J. PuZIUK, Nowożytne fajki z badań archeologicznych w Krakowie, „Materiały Archeologiczne” 2015, t. 40, s. 54-60; IDEM, Gliniane lulki z badań archeologicznych w Krakowie jako przyktad wschodnioeuropejskiego modelu palenia tytoniu w nowożytnym mieście, [w:] Jedza, pija, lulki pala. Kulturowe 
żołnierze (w szczególności liczny garnizon austriacki) praktykowali odmienne od mieszkańców obyczaje palenia tytoniu w fajce. Warto zauważyć, że armia ta składała się w znacznej mierze z polskiego rekruta, jednak w niektórych pułkach przeważali Niemcy, Czesi lub Węgrzy, którzy zwyczaje fajczarskie mogli realizować w przyborach przywożonych $\mathrm{z}$ rodzinnych stron ${ }^{17}$. Dowodzą tego prace wykopaliskowe prowadzone na wzgórzu wawelskim, gdzie rozpoznano akcesoria produkowane w krajach dawnego Imperium Habsburskiego i późniejszych Austro-Węgier, których użytkownikami byli stacjonujący tam żołnierze.

Badania archeologiczne realizowane na Wawelu w latach 1948-2011 doprowadziły do odkrycia najliczniejszego obecnie zbioru nowożytnych fajek na terenie Małopolski ${ }^{18}$. Kolekcja ta składa się z 890 pozostałości fajek jednorodnych, złożonych - lulek oraz akcesoriów porcelanowych ${ }^{19}$. Niewiele jest znalezisk zaliczanych do fajek jednorodnych ${ }^{20}$, które wiązać można w znacznej mierze z okupacją wzgórza wawelskiego przez wojska szwedzkie oraz pruskie w wiekach

aspekty korzystania z u̇zywek na przestrzeni dziejów. Używki w świetle źródet archeologicznych i historycznych, red. A. KLONDER, Bydgoszcz 2016, s. 171-186.

${ }^{17}$ J. BIENIARZÓWNa, J.M. MAEECKI, op. cit., s. 320.

18 M. SZEWCZYK-WOJTASIEWICZ, op. cit., s. 39-40.

19 Ibidem, s. 39. Warto dodać, że zbiór ten stale się powiększa w miarę postępujących prac badawczych toczących się na wzgórzu wawelskim.

${ }^{20}$ Przez fajkę jednorodną należy rozumieć akcesorium do palenia tytoniu wykonane z jednego kawałka gliny, składające się z główki, cybucha i ustnika, które stanowią nierozłączną całość. J. PuzıuK, Nowożytne fajki..., s. 52. Ten rodzaj fajki był przyborem zachodnioeuropejskiej tradycji palenia tytoniu, do najpopularniejszych zaliczały się egzemplarze produkowane w Holandii, zwłaszcza w warsztatach działających w Goudzie - vide: D.H. Duco, Marken van Goudse pijpenmakers 1660-1940, Leiden 1982; De Nederlandse kleipijp. Handboek voor dateren en determineren, Leiden 1987. Na obszarze Polski, znaleziska fajek jednorodnych przeważają w zachodniej i północnej części kraju, stanowiąc, oprócz wyrobów niderlandzkich i brytyjskich, również wytwórstwo pruskich manufaktur w Rościnie i Zborowskiem, produkujących takie akcesoria w okresie XVIII-XIX w. - vide: J. DĄBAL, Jednorodne fajki gliniane z manufaktury w Rościnie pozyskane na stanowisku przy ul. Szafera w Gdańsku. Próba interpretacji źródet w kontekście zmian spoteczno-ekonomicznych w okresie industrialnym, [w:] Archeologia Dolnego Miasta w Gdańsku. Pótnocno-zachodnia częśc kwartatu ulic Dtugie Ogrody, Szafarnia, Angielska Grobla, Św. Barbary, red. B. Bobowski, Gdańsk 2010, s. 73-86; B. GRABNY, P. NocuŃ, Ślaska Fabryka Fajek ze Zborowskiego - podsumowanie dwóch sezonów badań archeologicznych z lat 2013-2014, województwo ślaskie, [w:] Badania archeologiczne na Górnym Ślasku i ziemiach pogranicznych w latach 2013-2015, red. G. GlanC-ZAGAJA, Katowice 2016, s. 200-211; K. KwiATKOwSKI, Jednorodne fajki gliniane z badań kwartatu staromiejskiego w Stargardzie, „Materiały Zachodniopomorskie Nowa Seria” 2011, t. 6/7, s. 357-382; T. WiTKOWSKA, Manufaktura fajek glinianych z Rościna, gmina Myślibórz, „Materiały Zachodniopomorskie” 1989/90, t. 35/36, s. 283-301. 
XVII i XVIII ${ }^{21}$. Zdecydowanie najliczniejsze są odkrycia fajek złożonych - lulek, oraz przyborów porcelanowych, które stanowią materialny ślad obecności wojsk austriackich i austro-węgierskich w XIX i początkach XX w. Prace badawcze wykonywane w trakcie prowadzonej eksploracji ujawniły znaleziska nowożytnych akcesoriów do palenia tytoniu w wielu rejonach wykopaliskowych wzgórza wawelskiego ${ }^{22}$. W odkrycia tego typu zabytków bogaty jest rejon XV (obszar za pałacem, ogrody królewskie), znajdujący się w północno-wschodniej części wzgórza ${ }^{23}$. Jednak zdecydowanie najczęściej znaleziska takie były identyfikowane w południowo-zachodniej partii Wawelu, odpowiadającej rejonom VI (dziedziniec zewnętrzny) i VIII (przyziemie budynku nr 8, międzymurze fortyfikacji gotyckich i gwiaździstych, Baszta Złodziejska oraz teren między budynkiem nr 7 a Wikarówką), gdzie w okresie zaboru austriackiego funkcjonował sektor medyczny cytadeli, w którym znajdował się szpital i koszary dla rekonwalescentów wojennych (ryc. 3-4) ${ }^{24}$.

W powyższych rejonach rozpoznano znaczne ilości przyborów wykonanych z gliny, będących produktami słynnych warsztatów fajkarskich Monarchii Habsburskiej, oraz pozostałości fajek porcelanowych, które datowane są na okres od XIX do początków XX w.

Badania dowodzą, że wśród żołnierzy stacjonujących na Wawelu znaczną popularnością cieszyły się sygnowane lulki z różnych zakładów działających na terenie krajów Imperium Habsburskiego i późniejszych Austro-Węgier (ryc. 5)25.

21 Szwedzi okupowali Wawel w latach 1655-1657, natomiast wojska pruskie przebywały tam w okresie od 1794 r. do 1796 r. - vide: R. SKOwRON, op. cit., s. 204-206, 246-250.

22 Wzgórze wawelskie podzielone zostało według schematu stosowanego przy pracach archeologicznych na 16 jednostek (I-XVI) zwanych rejonami; vide: M. SZEWCZYK-WOJTASIEWICZ, op. cit., s. $10-11$.

23 Ibidem, s. 11.

24 Ibidem.

25 Fajka złożona - lulka - to akcesorium, które składa się z główki, cybucha i ustnika, przy czym każdy z komponentów stanowił osobny element i wykonany mógł być z innego materiału (ryc. 5). Główki, które wytwarzane były zwykle z gliny są najczęściej spotykaną pozostałością tego rodzaju akcesoriów w materiale archeologicznym. Cybuchy wykonywano zazwyczaj z drewna, wykorzystując takie odmiany jak jaśmin, wiśnia lub czereśnia. Niektóre z nich osiągały znaczą długość, charakteryzując się dodatkowo bogatą ornamentyką, co również podkreślać miało wysoki status społeczny właściciela fajki. Zakończeniem cybucha był ustnik, który produkowano z powszechnie dostępnych surowców - drewna, ceramiki oraz kamienia. Warto jednak zaznaczyć, że wytwarzano je również z koralu, kości słoniowej oraz bursztynu; vide: J. PuzIUK, Nowożytne fajki..., s. 52; IDEM, Gliniane lulki..., s. 175. Lulka stanowiła zasadniczy przyrząd wschodnioeuropejskiego modelu palenia tytoniu. Jej produkcją zajmowały 

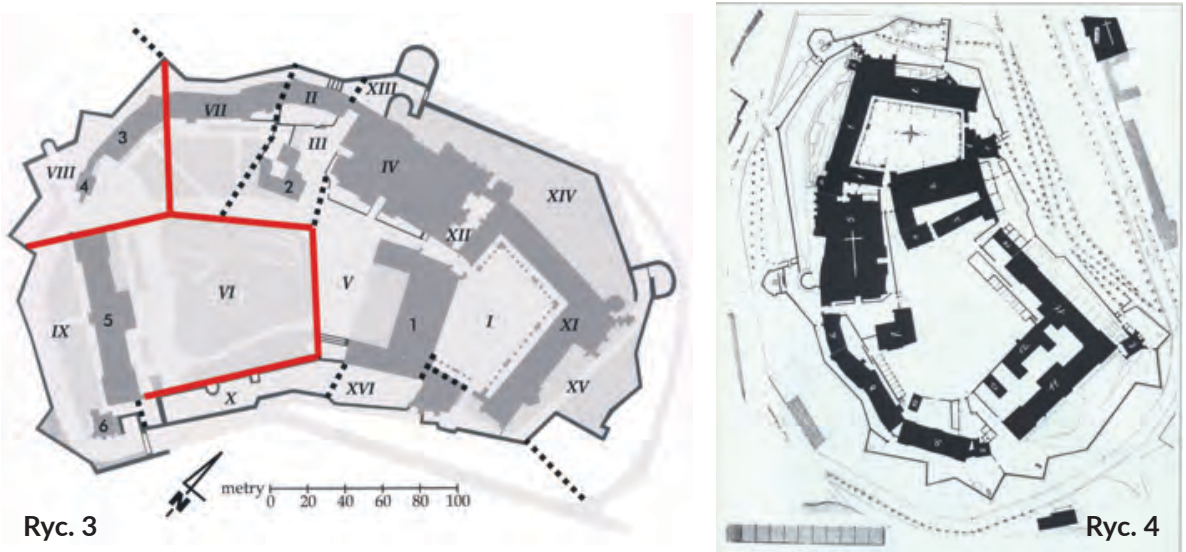

Ryc. 3. Podział wzgórza wawelskiego na rejony wykopaliskowe z wyszczególnieniem rejonu VI i VIII (czerwona linia), gdzie rozpoznano znaczne koncentracje znalezisk fajek (źródło: M. SZEWCZYK-WoJTASIEWICZ, Fajki z badań archeologicznych w zbiorach Zamku Królewskiego na Wawelu, Kraków 2017, s. 10)

Ryc. 4. Plan zabudowy wzgórza wawelskiego na początku XX w., z zachowanym kompleksem budynków szpitala wojskowego (11-14) i koszarami dla rekonwalescentów (9) (źródło: R. Skowron, Wawel. Kronika dziejów, Kraków 2001, s. 315)

Fajki te, charakteryzujące się wysokiej jakości rzemiosłem, wytwarzano przeważnie z gliny żelazistej, wypalając na kolor czerwony, stosując zdobnictwo z wykorzystaniem technik wyciskania, polerowania i pokrywania powierzchni zewnętrznej czarną angobą ${ }^{26}$. Bardzo często tego rodzaju akcesoria posiadały elementy dekoracyjne wykonane z metalu w postaci okuć zwanych kryzami i wieczek nazywanych kapturkami ${ }^{27}$. Niektóre z okazów, zaopatrzone są w sygnatury i znaki warsztatowe, które dają możliwość identyfikacji kraju producenta, jak i niekiedy samego wytwórcy. W znaleziskach wawelskich rozpoznane zostały przybory o proweniencji słowackiej, austriackiej i węgierskiej. Wśród akcesoriów pochodzenia słowackiego dominują fajki z Bańskiej Szczawnicy wyprodukowane w słynnych rodzinnych zakładach Hönigów (sygnowane napisem

się warsztaty garncarskie oraz wyspecjalizowane zakłady fajkarskie, głównie na obszarze Europy Środkowo-Wschodniej i Południowej. Na terenie Polski, znaleziska tego typu akcesoriów dominują zwłaszcza w południowej części kraju - vide: J. PUZIUK, Gliniane lulki..., s. 173; IDEM, Historia i archeologia wschodnioeuropejskiego modelu palenia tytoniu w okresie nowożytnym, [w:] Ślaska fabryka fajek glinianych w Zborowskiem. Wyniki badań, studia, konteksty, red. B. PAPAJ, Chorzów 2020, s. 14-33.

${ }^{26}$ M. SZEWCZYK-WojTASIEWICZ, op. cit., s. 82-84 (tablice VIII-XXI).

27 Ibidem, s. 417. 


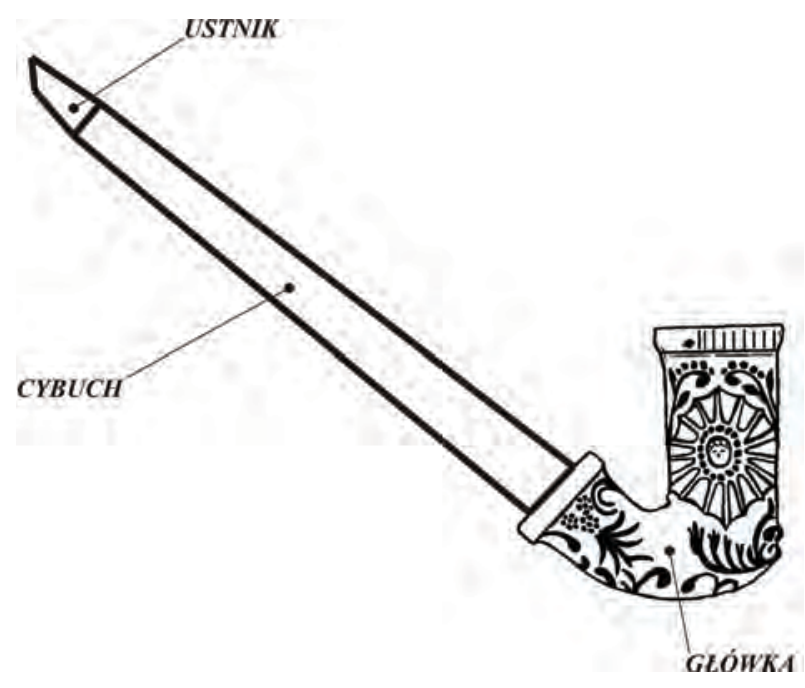

Ryc. 5. Rekonstrukcja fajki złożonej - lulki (opracowanie: J. Puzıuk)

„M. HÖNIG WWE SCHEMNITZ”) oraz Schmidtów (sygnowane napisem „J. SCHMIDT SCHEMNITZ”) (ryc. 6) ${ }^{28}$.

Zidentyfikowano również lulki ze słowackiej Kremnicy, pochodzące z warsztatu znanego fajkarza Eliáša Štiasnego (sygnowane napisem „E. STIASNY KREMNITZ” ${ }^{29}$. Przybory pochodzenia austriackiego, odnosiły się głównie do wyrobów wykonanych w Wiener Neustadt, w szczególności w zakładach Mathiasa Amstättera (sygnowane napisem „AMSTÄTTER/WIENER.NEUSTADT”) oraz Antona Ressa (sygnowane napisem „A. RESS”) ${ }^{30}$. Sporadycznie rozpoznawano produkty znanej w Monarchii Habsburskiej rodzinnej wytwórni Partschów, działającej w Theresienfeldzie w Dolnej Austriii ${ }^{31}$. Najrzadziej wśród znalezisk wawelskich reprezentowane są natomiast egzemplarze proweniencji węgierskiej, które są wytworami niezidentyfikowanych producentów z miejscowości Podrecsány (sygnowane napisem „Podrecs”) oraz Körmend (sygnowane napisem „Kormeny”) (ryc. 7) 32 .

\footnotetext{
${ }^{28}$ Ibidem, s. 85-105 (tablice VIII-XIV).

29 Ibidem, s. 115-120 (tablice XV-XVI).

${ }^{30}$ Ibidem, s. 124-129 (tablice XVII-XVIII).

${ }^{31}$ Ibidem, s. 133-136 (tablica XIX).

32 Ibidem, s. 139-142 (tablica XX).
} 

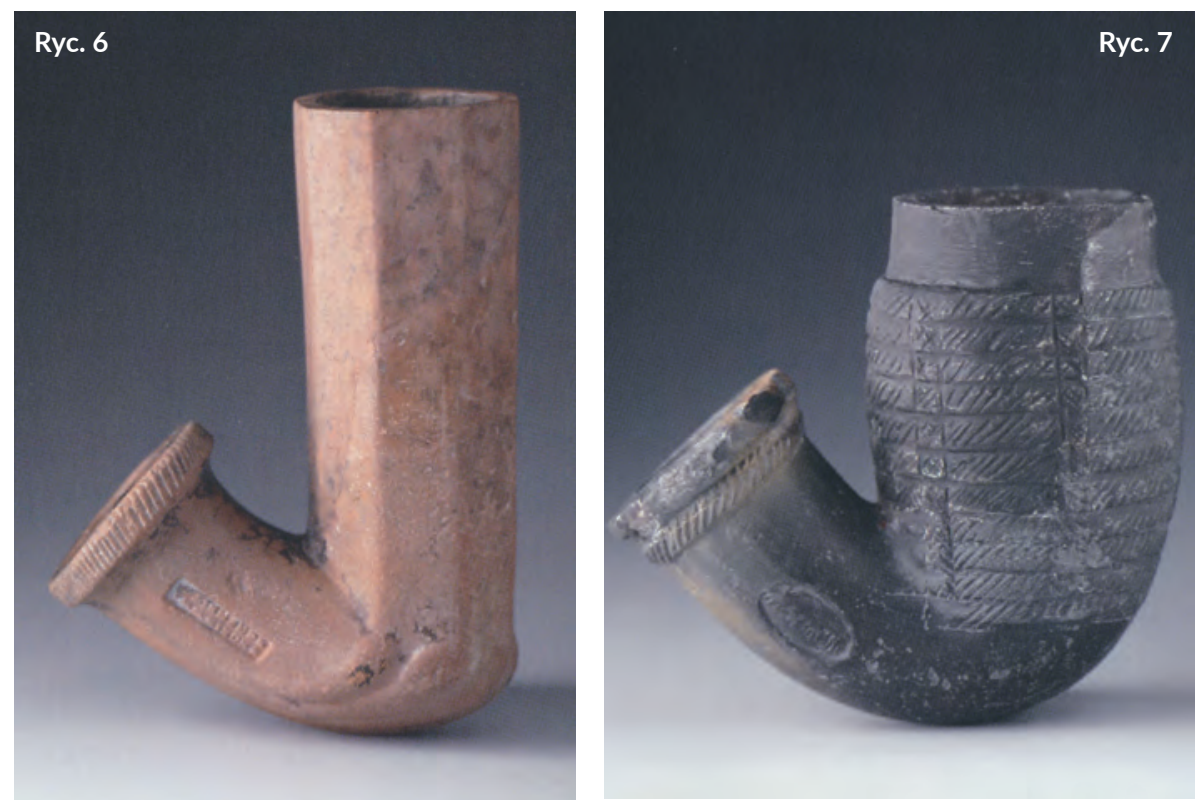

Ryc. 6. Gliniana lulka wyprodukowana na Słowacji (Bańska Szczawnica) z sygnaturą „M. HÖNIG WWE SCHEMNITZ”, znaleziona na Wawelu, druga połowa XIX w. (źródło: M. SzEWCZYK-WoJTASIEWICZ, Fajki w zbiorach..., s. 40)

Ryc. 7. Gliniana lulka wyprodukowana na Węgrzech (Podrecsány) z sygnaturą „Kormeny", znaleziona na Wawelu, trzecia ćwierć XIX w. (źródło: M. SZEWCZYK-WoJTASIEWICZ, Fajki w zbiorach..., s. 51)

Żołnierze austriaccy i austro-węgierscy oddawali się nałogowi palenia tytoniu również w innym rodzaju lulki, która znana jest w polskiej literaturze archeologicznej pod nazwą fajki „kawiarnianej”33. Co ciekawe, pojawienie się tego typu akcesoriów związane było z dziewiętnastowieczną modą, popularną głównie wśród mieszczan Europy środkowej, która upowszechniała tzw. kulturę kawiarnianą, polegającą na spędzaniu wolnego czasu przy piciu kawy i paleniu fajki w miejskich kawiarniach ${ }^{34}$. Zwyczaje te nie były zatem obce również wojsku stacjonującemu na Wawelu. Fajki „kawiarniane” wytwarzane z białej

${ }^{33}$ J. PUZIUK, op. cit., s. 56-57.

${ }^{34}$ M. VYŠOHLíD, Keramické dýmky $v$ archeologických nálezech a jejich vypovidaci možnosti, "Archeologie ve Středních Čechách” 2009, vol. 13, s. 984; Dvojdilné keramické dýmky 17.-19. stoleti $z$ archeologických nálezů $v$ Čechách, [w:] História výroby fajok a archeologické nálezy fajok na Slovensku, red. J. DANO, Levice 2011, s. 71-88. 
gliny kaolinowej, wyróżniały się niezwykle bogatą ornamentyką, szczególnie wykorzystaniem motywów geometryczno-linearnych oraz roślinnych (zwłaszcza florystycznych). Akcesoria tego typu (zwane Kaffeehauspfeifen), cieszące się największą renomą, produkowane były w wytwórniach niemieckich (Kolonia) i austriackich (Wiedeń) ${ }^{35}$. Podobne fajki wytwarzano również w słowackiej Kremnicy oraz na Węgrzech ${ }^{36}$.

Bardzo popularne, szczególnie w Czechach i na Słowacji, były imitacje fajek typu Kaffeehauspfeifen, które w znacznych ilościach produkowało przedsiębiorstwo Mórica Mahlera w czeskim Kolinie ${ }^{37}$. W źródłach wawelskich rozpoznano fajki „kawiarniane” proweniencji austriackiej, pochodzące z warsztatów wiedeńskich (sygnowane napisem „MEIDLING”) oraz akcesoria wytwarzane w zakładach słowackiej Kremnicy (sygnowane napisami „KÖRMÖCZ lub HONI PAR” ${ }^{38}$. Najczęściej jednak identyfikowane były produkty przypisywane czeskiej wytwórni Mahlera w Kolinie (sygnowane napisami „PATENT COLN”, „PATENT CAFE”, „CAFE COLN”) (ryc. 8) ${ }^{39}$.

W asortymencie dziewiętnastowiecznych akcesoriów do palenia tytoniu, wykorzystywanych przez żołnierzy przebywających na Wawelu, zaznaczają się bardzo wyraźnie fajki porcelanowe (ryc. 9) ${ }^{40}$.

Znaleziska takie, identyfikowane w materiale źródłowym ze wzgórza wawelskiego, należy łączyć głównie z produkcją pochodzenia niemieckiego (pruskiego)

35 M. Bielich, M. ČUrnÝ, Pipe finds from Nitra and Nitra pipe production, „Studies in Post-Medieval Archaeology" 2009, No. 3, s. 354; M. VYšOHLíD, Keramické dýmky..., s. 984.

${ }^{36}$ M. VYŠOHLíD, Keramické dýmky..., s. 984.

${ }^{37}$ M. ČURNÝ, P. ŠIMČIK, M. BIELICH, Nálezy keramických fajok $z$ archeologických výskumov a prospekcii na Slovensku, „Študijné zvesti Archeologického ústavu Slovenskej Akademie Vied” 2013, Roč. 53, s. 96.

${ }^{38}$ M. SZEWCZYK-WOJTASIEWICZ, op. cit., s. 59 (tablica III).

${ }^{39}$ Ibidem (tablice III-V).

${ }^{40}$ Fajki porcelanowe zalicza się do akcesoriów złożonych, składających się z główki, zbiornika kondensatowego (tzw. osadnika), cybucha oraz ustnika (ryc. 9). W starszych egzemplarzach takich fajek, główka i zbiornik na kondensat stanowiły całość, którą przedzielała pozioma ścianka z otworem (lub otworami). Z porcelany wykonywane były główki oraz zbiorniki na kondensat, które są najczęściej rozpoznawaną pozostałością tego typu fajek w źródłach wykopaliskowych. Do produkcji cybuchów (niekiedy znacznej długości) wykorzystywano głównie drewno, natomiast ustniki mogły być wykonywane również z bursztynu lub ebonitu. Ibidem, s. 29-31. Dużą popularnością cieszyły się główki i zbiorniki na kondensat produkowane przez środkowoeuropejskie manufaktury porcelany. $\mathrm{Na}$ terenie Polski, znaleziska takich przyborów rozpoznawano w znacznej większości w kompleksach dawnych twierdz: J. Puzıuk, Nowożytne fajki..., s. 62. 

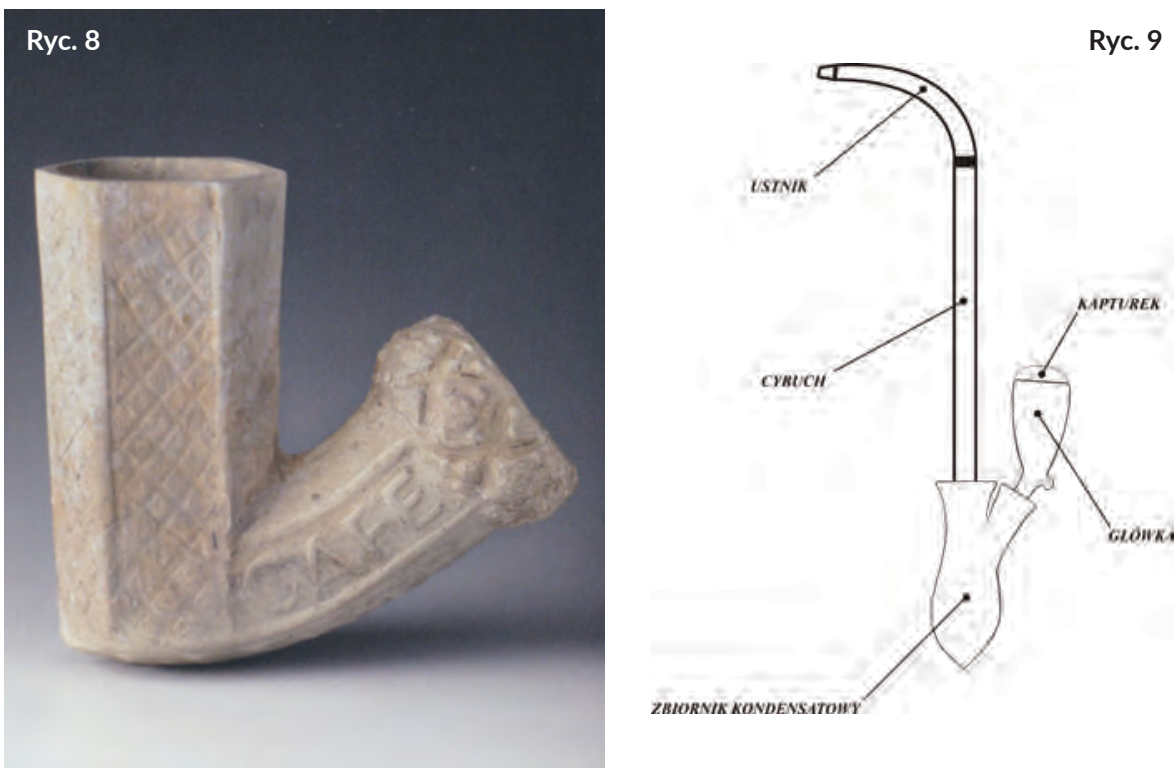

Ryc. 8. Gliniana lulka wyprodukowana w Czechach (Kolin) z sygnaturą "CAFE PATENT”, znaleziona na Wawelu, druga połowa wieku XIX-początek XX w. (źródło: M. SZEWCZYK-WoJTASIEWICZ, Fajki w zbiorach..., s. 48)

Ryc. 9. Rekonstrukcja fajki złożonej z główką porcelanową (opracowanie: J. PuzıUK)

i austro-węgierskiego. Charakterystycznymi pozostałościami tego rodzaju akcesoriów, są porcelanowe główki oraz wykonywane z tego samego materiału zbiorniki kondensatowe (tzw. osadniki) (ryc. 10-11) ${ }^{41}$.

Fajki te wyróżniają się bogatą ornamentyką z zastosowaniem podszkliwnej lub naszkliwnej barwnej dekoracji malowanej oraz techniki kalkomanii, polegającej na nanoszeniu przedrukowanego obrazu na porcelanie ${ }^{42}$. Ornamenty te prezentowały wyobrażenia bukoliczne, rodzajowe (np. przedstawienia polowań, sceny wojskowe) oraz często spotykane krajobrazy (np. widoki gór, zamków) i sylwetki różnych postaci (np. dam dworu, wojskowych) ${ }^{43}$. Pojawiają się również nieliczne egzemplarze z krótkimi sentencjami lub inskrypcjami towarzyszący-

${ }^{41}$ Ibidem, s. 360-416 (tablice LXII-LXXIV).

${ }^{42}$ Ibidem, s. 22-23.

43 Ibidem, s. 388-400 (tablice LXVIII-LXXII). 

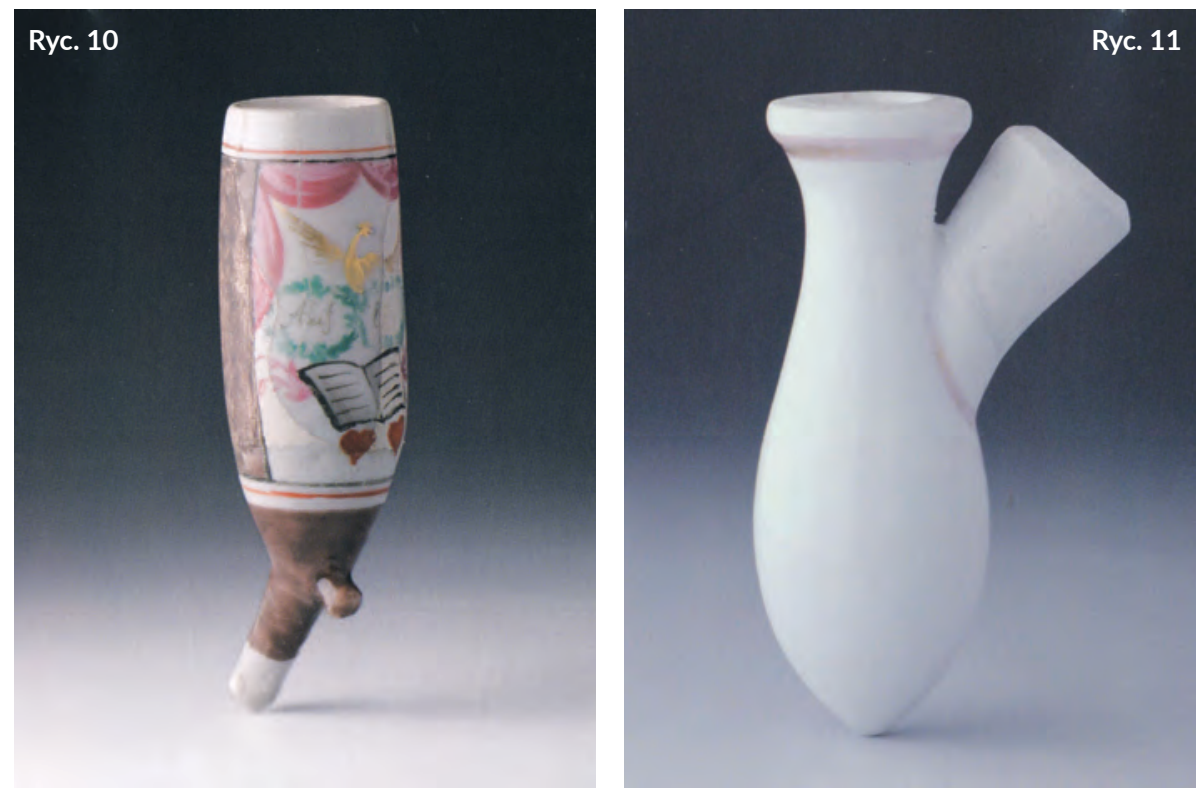

Ryc. 10. Główka fajki porcelanowej znaleziona na Wawelu, XIX w.

(źródło: M. SzEWCZYK-WoJTASIEWICZ, Fajki w zbiorach..., s. 59)

Ryc. 11. Porcelanowy zbiornik na kondensat znaleziony na Wawelu, XIX w.

(źródło: M. SZEWCZYK-WoJTASIEWICZ, Fajki w zbiorach..., s. 60)

mi dekoracjom (np. „Jakob Dreibl Salmhof bri Marcheg”, „VIVAT FRANZ") ${ }^{44}$. Przybory tytoniowe wykonane z porcelany, obok swojej podstawowej funkcji użytkowej, spełniały bardzo często rolę bibelotów lub pamiątek, które ofiarowywano np. przedstawicielom cechów rzemieślniczych ${ }^{45}$. Jednak najjaskrawszym tego przykładem był zwyczaj polegający na obdarowywaniu żołnierzy odchodzących do rezerwy ozdobnymi fajkami z dekorowanymi główkami porcelanowymi; zwyczaj ten w XIX w. i początku wieku XX powszechnie stosowano w armii austriackiej i niemieckiej (tzw. fajka rezerwisty) (ryc. 12) ${ }^{46}$.

\footnotetext{
${ }^{44}$ Ibidem, s. 364, 399, 404 (tablica LXIII) i 467 (tablica LXXII).

45 Ibidem, s. 22.

46 J. Puziuk, Fajki z badań..., s. 80.
} 


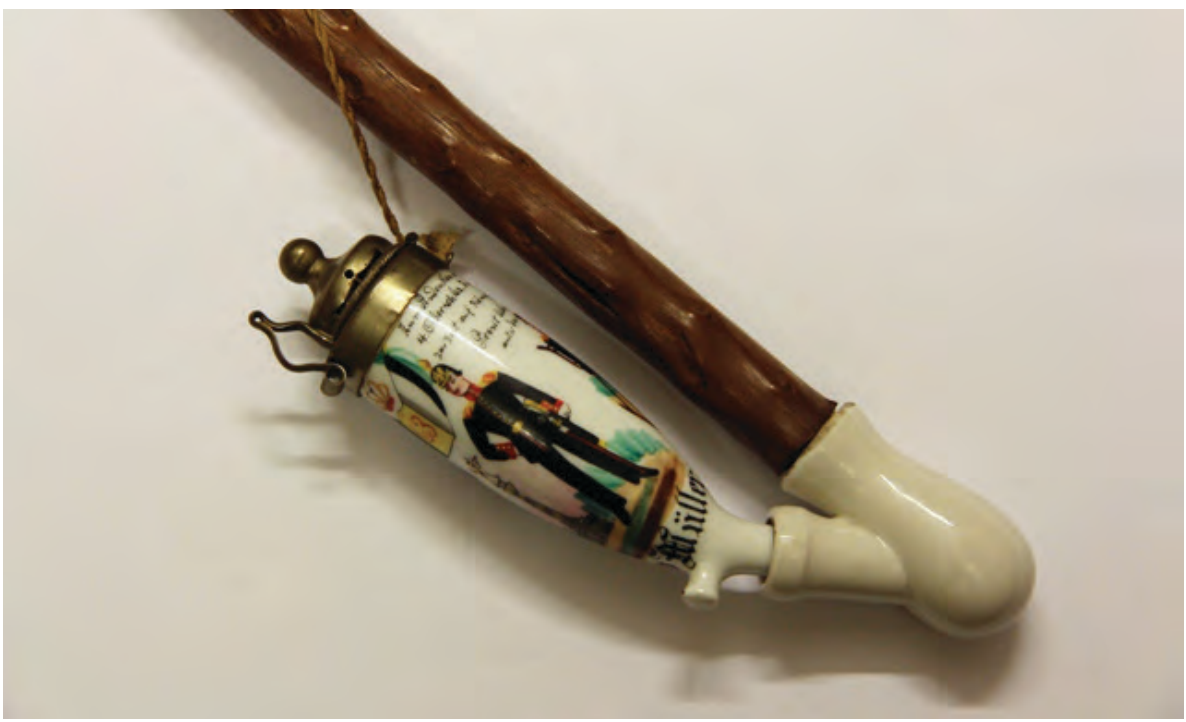

Ryc. 12. Fajka rezerwisty 63. Górnośląskiego Pułku Piechoty, należąca do żołnierza Gustava Müllera, 1894 r.

(źródło: zbiory Muzeum Śląska Opolskiego, https://muzeum.opole.pl/, dostęp: 12 XI 2020)

Istnieje duże prawdopodobieństwo, że fajki porcelanowe rozpoznawane na Wawelu stanowią pozostałość właśnie takich pamiątek, które otrzymywali rezerwiści kończący służbę w krakowskiej cytadeli. Świadczyć o tym również mogą zachowane na główkach fajek ornamenty, utrzymane w luźnej konwencji obyczajowej (np. przedstawienia kobiet) oraz licznymi odniesieniami do tematyki wojkkowej (ryc. 13) ${ }^{47}$. Co ciekawe i warte podkreślenia, mimo pamiątkarskiego charakteru takich akcesoriów, spełniały one dalej swoje funkcje użytkowe, czego dowodem są często rozpoznawane ślady użytkowania na główkach i zbiornikach kondensatowych.

Pozostałości fajek zidentyfikowane w kontekście żołnierzy stacjonujących na krakowskim Wawelu w XIX w. i początku wieku XX, odzwierciedlają przywiązanie tego środowiska do nałogu tytoniowego, który praktykowany był przy użyciu akcesoriów nawiązujących do wschodnioeuropejskiego modelu palenia. Co warte podkreślenia, tytoń ceniony był nie tylko za swoje wartości relaksacyjne, ale spełniać musiał również niepoślednią rolę w procesie zdrowienia

${ }^{47}$ M. SZEWCZYK-WojTASIEWICZ, op. cit., s. 365-399, 407 (tablica LXII), 445 i 448 (tablica LXIX), 451 i 455 (tablica LXX), 456 (tablica LXXI) i 468 (tablica LXXII). 


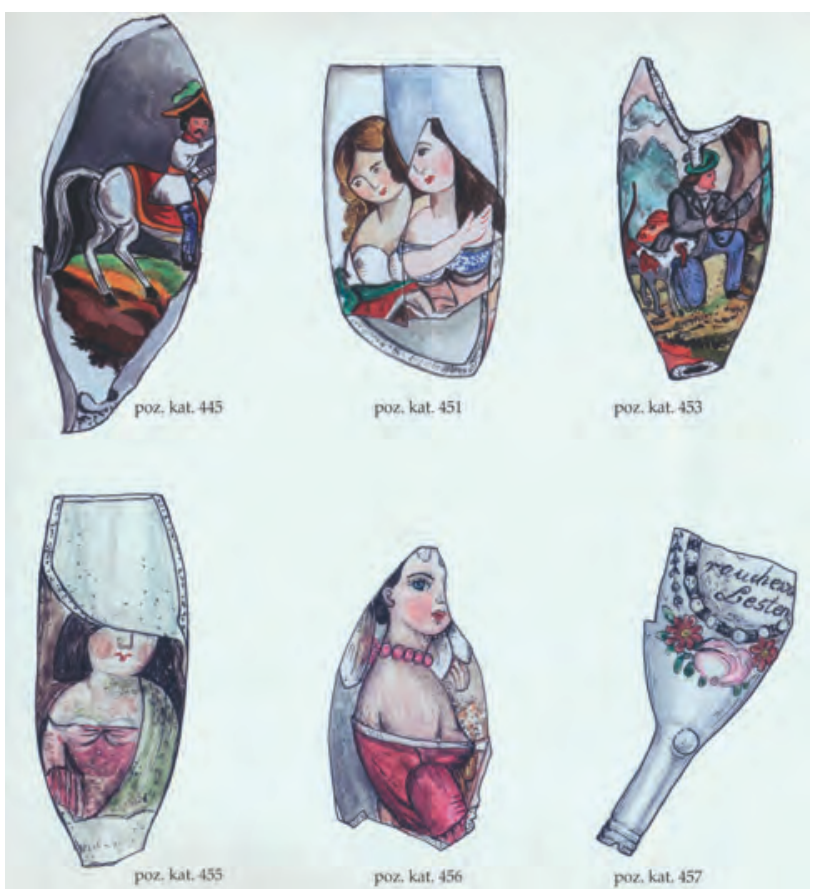

Ryc. 13. Główki fajek porcelanowych znalezionych na Wawelu, zdobione barwnymi scenami rodzajowymi, XIX w.

(źródło: M. SzEWCZYK-WoJTASIEWICZ, Fajki z badań..., s. 445)

i psychicznej rehabilitacji żołnierzy, czego dowodzą znaczne ilości znalezisk fajek w rejonach zabudowań dawnego szpitala i domu rekonwalescentów armii austriackiej i austro-węgierskiej. Zaznacza się ponadto wpływ miejskiej kultury palenia, która mogła inspirować żołnierzy do przyjęcia niektórych obyczajów i praktyk spędzania wolnego czasu z fajką, czego najlepszym przykładem są odkrycia na wawelskim wzgórzu akcesoriów „kawiarnianych”. Odkrywane na Wawelu fajki, w szczególności sygnowane lulki z różnych warsztatów Imperium Habsburskiego i późniejszych Austro-Węgier, być może odzwierciedlają skład narodowościowy garnizonu krakowskiego, z pewnością jednak pokazują, że znaczną popularnością wśród stacjonujących tam żołnierzy cieszyły się akcesoria produkowane na terenie Słowacji, Czech lub Austrii.

Nowożytne przybory tytoniowe zaliczane do pozostałości materialnych kultury żołnierskiej stanowią zatem znakomite źródło informacji dotyczące mody i obyczajów ówczesnych wojskowych, co z pewnością uzupełniać będą kolejne badania archeologiczne, nie tylko prowadzone w miastach. 


\section{BIBLIOGRAFIA}

\section{Opracowania}

Bielich M., Nálezy fajok zo Šale a okolia, „Študijné zvesti Archeologického ústavu Slovenskej Akademie Vied” 2016, Roč. 59, s. 125-146.

Bielich M., Čurný M., Pipe finds from Nitra and Nitra pipe production, „Studies in Post-Medieval Archaeology" 2009, No. 3, s. 337-362.

Bieniarzówna J., Małecki J.M., Dzieje Krakowa. Kraków w latach 1796-1918, t. 3, Kraków 1979.

Brack de A.F., Forpoczty kawalerii lekkiej. Wspomnienia, Oświęcim 2012.

Čurný M., Šimčik P., Bielich M., Nálezy keramických fajok z archeologických výskumov a prospekcii na Slovensku, „Študijné zvesti Archeologického ústavu Slovenskej Akademie Vied" 2013, Roč. 53, s. 85-101.

Dąbal J., Jednorodne fajki gliniane z manufaktury $w$ Rościnie pozyskane na stanowisku przy ul. Szafera w Gdańsku. Próba interpretacji źródet w kontekście zmian spoteczno-ekonomicznych wokresie industrialnym, [w:] Archeologia Dolnego Miasta w Gdańsku. Pótnocno-zachodnia część kwartatu ulic Dtugie Ogrody, Szafarnia, Angielska Grobla, Św. Barbary, red. B. Bobowski, Gdańsk 2010, s. 73-86.

Duco D.H., De Nederlandse kleipijp. Handboek voor dateren en determineren, Leiden 1987.

Duco D.H., Marken van Goudse pijpenmakers 1660-1940, Leiden 1982.

Gačić D., Glinene lule sa Petrovaradinske tvrdave, "Journal Museum of Applied Art" 2008/2009, Jou. 4/5, s. 7-18.

Gačić D., Pipes from Petrovaradin fortress, Serbia, in the collection of Novi Sad City Museum, "Journal of the Académie Internationale de la Pipe” 2010, vol. 3, s. 121-129.

Gačić D., The pipes from museum collections of Serbia, Novi Sad 2011.

Grabny B., Nocuń P., Ślaska Fabryka Fajek ze Zborowskiego - podsumowanie dwóch sezonów badań archeologicznych z lat 2013-2014, województwo ślaskie, [w:] Badania archeologiczne na Górnym Ślasku i ziemiach pogranicznych w latach 2013-2015, red. G. Glanc-Zagaja, Katowice 2016, s. 200-211.

Kuśnierz J., Ceramiczne gtówki fajek ze zbiorów Muzeum Zamojskiego w Zamościu na tle krótkiej historii palenia tytoniu w Europie i Polsce, „Zamojsko-Wołyńskie Zeszyty Muzealne" 2014, t. 6, s. 123-154.

Kwiatkowski K., Jednorodne fajki gliniane z badań kwartatu staromiejskiego w Stargardzie, „Materiały Zachodniopomorskie Nowa Seria” 2011, t. 6/7, s. 357-382.

Kwiatkowski K., Ulotna historia. Fajki gliniane z badań w Stargardzie, Stargard 2012.

Meyza K., Fajki gliniane z XVII w. i pierwszej potowy XVIII w. z badań archeologicznych Zamku Królewskiego i Starego Miasta w Warszawie, „Almanach Muzealny” 1997, t. 1, s. 31-44. 
Puziuk J., Fajki z badań archeologicznych w Krakowie - źródto mówiace o tradycji, obyczajach i handlu mieszkańców nowożytnego miasta, [w:] Zielonogórskie Spotkania Źródtoznawcze. Na tropie źródta i jego interpretacji, red. M. Dalidowicz, J. Dudek, A. Górski, Zielona Góra 2015, s. 77-88.

Puziuk J., Gliniane lulki z badań archeologicznych $w$ Krakowie jako przyktad wschodnioeuropejskiego modelu palenia tytoniu w nowożytnym mieście, [w:] Jedza, pija, lulki pala. Kulturowe aspekty korzystania z używek na przestrzeni dziejów. Używki w świetle źródet archeologicznych i historycznych, red. A. Klonder, Bydgoszcz 2016, s. 171-186.

Puziuk J., Historia $i$ archeologia wschodnioeuropejskiego modelu palenia tytoniu $w$ okresie nowożytnym, [w:] Śląska fabryka fajek glinianych w Zborowskiem. Wyniki badań, studia, konteksty, red. B. Papaj, Chorzów 2020, s. 13-37.

Puziuk J., Nowożytne fajki z badań archeologicznych $w$ Krakowie, „Materiały Archeologiczne" 2015, t. 40, s. 51-85.

Skowron R., Wawel. Kronika dziejów, Kraków 2001.

Szewczyk-Wojtasiewicz M., Fajki w zbiorach Zamku Królewskiego na Wawelu, Kraków 2011.

Szewczyk-Wojtasiewicz M., Fajki z badań archeologicznych w zbiorach Zamku Królewskiego na Wawelu, Kraków 2017.

Vyšohlíd M., Bohemia, "Journal of the Académie Internationale de la Pipe” 2009, vol. 2, s. $17-25$.

Vyšohlíd M., Dvojdilné keramické dýmky 17.-19. stoleti z archeologických nálezů v Čechách, [w:] História výroby fajok a archeologické nálezy fajok na Slovensku, red. J. Dano, Levice 2011, s. 71-88.

Vyšohlíd M., Keramické dýmky v archeologických nálezech a jejich vypovídací možnosti, „Archeologie ve Středních Čechách” 2009, vol. 13, s. 965-1000.

Witkowska T., Fajki z badań archeologicznych na placu Dominikańskim we Wroctawiu, „Silesia Antiqua” 1998, t. 39, s. 283-336.

Witkowska T., Manufaktura fajek glinianych z Rościna, gmina Myślibórz, „Materiały Zachodniopomorskie" 1989/90, t. 35/36, s. 283-301.

Zabytki architektury i budownictwa w Polsce - Kraków, red. J. Czaj-Waluś, Warszawa 2007.

\section{Netografia}

https://muzeum.opole.pl/ (dostęp: 12 XI 2020).

https://pl.pinterest.com/pin/729090627173767948/ (dostęp: 16 XII 2020).

https://pl.pinterest.com/pin/729090627173768025/ (dostęp: 16 XII 2020). 
Jakub Puziuk

\section{URBAN PIPE SMOKING TRADITION IN A SOLDIER'S ETHOS. ARCHAEOLOGICAL FINDS OF ACCESSORIES FOR SMOKING IN THE CONTEXT OF SOLDIERS STATIONED AT WAWEL IN KRAKÓW}

Summary. Tobacco smoking for soldiers in the modern period was not only a relaxing function, but also a specific therapeutic therapy. This plant has long been perceived through the prism of a therapeutic herb (herba panacea) recommended as a universal medical preparation. The culture of smoking tobacco in a pipe has achieved a high degree of development, especially in the Habsburg Empire and the later Austro-Hungarian state, which can be confirmed by archaeological finds of utensils related to this period. Interpretation of the historical context of such sources very often indicates that their users were the military community, which, especially during the Austro-Hungarian domination, was stationed in large numbers in an extensive network of forts and barracks, often located in urban areas. Krakow was an example of such an urban center, being one of the key military bases. The most important point of defense of the fortress built in Krakow was the Wawel Hill, which in 1848 was officially transferred to the barracks for Austrian troops. Archaeological research carried out at Wawel in the years 1948-2011 led to the discovery of the most numerous collection of modern pipes in Lesser Poland. The most magnificent are the finds of stub-stemmed pipes and porcelain utensils, which constitute the material trace of the presence of Austrian and Austro-Hungarian troops in the $19^{\text {th }}$ century and at the beginning of the $20^{\text {th }}$ century. These works prove that among the soldiers stationed at Wawel, high-quality marked pipe bowls, produced in various workshops operating in the countries of the Habsburg Empire and later Austro-Hungary, were very popular. The soldiers indulged in tobacco smoking also in another variant of bowls, which is known as the Café-type pipe. The appearance of this type of accessories was related to the $19^{\text {th }}$ century fashion, popular especially among the burghers of Central Europe, which popularized the so-called "Café culture", which consists in spending free time drinking coffee and smoking pipes in city cafes. Porcelain pipes are also present in the assortment of $19^{\text {th }}$ century smoking accessories used by soldiers. Their characteristic remains are porcelain bowls and water bags made of the same material. With a high degree of probability, this type of utensils recognized at Wawel are fragments of the armorial pipes, which were given as souvenirs to soldiers leaving the service in the Krakow citadel. The remains of pipes identified in the context of soldiers stationed at Wawel Hill reflect the attachment of this community to the tobacco addiction, which was practiced in accessories referring to the Eastern European model of smoking. Tobacco was valued not only for its relaxation values, but also played an important role in the process of healing and mental rehabilitation of soldiers, as evidenced by the large number of finds of pipes in the areas of the buildings of the former garrison hospital. Moreover, the influence of the urban smoking culture is noticeable, which inspired the use of some customs and practices of spending free time with the pipe among soldiers, the best example of which are the discovery of Café-type pipes on the Wawel Hill.

Keywords: stub-stemmed pipe, porcelain pipe, Krakow, Wawel Hill, Austro-Hungary, Habsburg Empire, Krakow Fortress, smoking 